\title{
Ambidexterity in Public Organizations with an Emphasis on Managers' Psychological Capital
}

\author{
Sohrab Ghanizadeh, Farzad Sattari Ardabili*, Mohammad Kheirandish, Eshagh Rasouli, \\ Mohammad Hassanzadeh
}

Department of Management, Ardabil Branch, Islamic Azad University, Ardabil, Iran

\begin{tabular}{|c|c|}
\hline & ABSTRACT \\
\hline Keywords: & \multirow{7}{*}{$\begin{array}{l}\text { The purpose of the present research is to propose a psychological framework for managers' } \\
\text { ambidexterity in public organizations. The data were collected through } 11 \text { interviews } \\
\text { conducted over five months. The saturation was reached at nine interviews using conventional } \\
\text { content analysis. As a result, eight factors were identified to achieve ambidexterity in public } \\
\text { organizations, including courage, gratitude, spirituality, creativity, resilience, optimism, hope, } \\
\text { and self-efficacy. These factors can be used to develop a new framework for ambidexterity in } \\
\text { public non-profit organizations. This framework can also provide a psychological basis for } \\
\text { creating and strengthening managers' ability to plan ambidextrous behaviors. }\end{array}$} \\
\hline Ambidexterity, Managers' & \\
\hline Psychological Capital, & \\
\hline Exploration and Exploitation & \\
\hline Received & \\
\hline 24 September 2020 & \\
\hline Received in revised form & \\
\hline
\end{tabular}

Accepted

21 December 2020

*Correspondence:

F.sattari@iauardabil.ac.ir

Organizations continually face serious challenges in managing competing objectives. Some organization theorists consider the achievement of these objectives as the basic philosophy of forming organizations (Birkinshaw \& Gupta, 2013). Organizations require both exploration and exploitation to ensure their present and future interests (Levinthal \& March, 1993). The ability of organizations to simultaneously manage and balance these two strategies (improve productivity and innovation) can be traced back to the seminal work of March (1991), who argued that organizations must develop both the existing operations and new products (Palm \& Lilja, 2017). 
An organization's ability to simultaneously perform differing and often competing activities is referred to as organizational ambidexterity (Simsek, Heavey, \& Veiga, 2009). Organizational ambidexterity is also defined as the ability to exploit existing resources and competencies while exploring innovation and new challenges (Chng \& Le Huy, 2019).

Individuals are essential sources of organizational ambidexterity (Gibson \& Birkinshaw, 2004) that must act ambidextrously to demonstrate alignment and adaptation. Ambidextrous organizations need ambidextrous senior teams and managers who can understand and be sensitive to different businesses' needs (O'Reilly \& Tushman, 2004).

Early studies on ambidexterity have been focused on the organizational level, with little empirical or theoretical work at the lower level of operations (Turner \& Lee-Kelley, 2013). The few studies on ambidexterity at the individual level have focused on managers' behavioral actions to balance the exploration of new information and exploit existing knowledge (Good \& Michel, 2013). Organizational ambidexterity is useful in understanding the outcomes of the public-sector organization. They are ultimately focused on non-financial performance and efficient resource allocation to meet stakeholders' needs (Umans, Smith, Andersen, \& Planken, 2018). Public organizations must be simultaneously innovative and efficient to overcome today's challenges, such as demographic changes and digitization (Cannaerts, Segers, \& Warsen, 2020).

\section{Literature Review}

\section{Ambidexterity in Public Organizations}

Organization theorists have recently used the term ambidexterity, or individuals' ability to use both hands equally well, as a metaphor to describe organizations (Smith \& Umans, 2015). The word "ambidexterity" is derived from the Latin roots ambi-, meaning "both", and dexter, meaning "right" or "favorable", which literally means "both right" or "both favorable" (Maier, 2015). The concept of organizational ambidexterity was popularized in the 1990s and has received increasing attention from researchers in the last two decades (Lis, Józefowicz, Tomanek, \& Gulak-Lipka, 2018). Duncan (1976) was the first to use the term organizational ambidexterity to refer to dual structures that are implemented to manage trade-offs between alignment and adaptation. However, this concept can be indirectly traced to the works of March and Simon (1958), Bruns and Stalker (1961), Woodward (1965), and Lawrence and Lorsch (1967). For example, Bruns and Stalker (1961) examined how the opposing nature of stable and turbulent business environments lead to the development of "mechanistic" and "organic" firm management systems (Chng \& Le Huy, 2019). Ambidexterity in an organization's ability to manage the tensions arising from the contradictory demands for exploration and exploitation (Maclean, Harvey, Golant, \& Sillince, 2020), associated with specific cognitive processes (Laureiro-Martinez, Brusoni, \& Zollo, 2010).

Organizational ambidexterity has been mostly studied in the private sector. There have been calls for transferring critical concepts in organizational studies such as organizational ambidexterity to the public sector. However, further research is required to focus on public organizations to generalize private-sector findings to the public sector, particularly in the field of public administration (Kobarg, Wollersheim, Welpe, \& Spörrle, 2017), since the public and private sectors have other conditions to achieve ambidexterity (Cunningham \& Kempling, 2009; Lee, Hwang, \& Choi, 2012). These different circumstances pose the question of whether public organizations can be ambidextrous at all (Palm \& Lilja, 2017). Organizational ambidexterity is a useful concept in understanding public organizations' non-financial outcomes (Umans et al., 2018). Bryson, Boal and Rainey (2008) argue that government agencies can function ambidextrously and have the capacity 
as well as the opportunity to adopt ambidextrous structures and cultures (Bryson et al., 2008). Of course, despite the somewhat similar contents and goals of public organizations, there is no one best solution, rather multiple paths for public organizations to become ambidextrous (Cannaerts et al., 2020).

In public organizations, innovation is associated with exploration activities (Gieske, George, Meerkerk, \& Buuren, 2020). It is defined as implementing a new concept (technical, organizational, policymaking, services, etc.), which changes and improves public-sector functioning and outcomes (Hartley, 2005). Exploration activities refer to the emergence, implementation, and diffusion processes of radical innovation (Cannaerts, Segers, \& Henderickx, 2016). On the other hand, optimization is associated with exploitation activities (Gieske et al., 2020) and is defined as an incremental improvement of current policies, processes, techniques, and services in line with past practices (Osborne \& Brown, 2011). Exploitation focuses on the provision of services and efficiency (Cannaerts et al., 2016). However, there is little evidence on ambidextrous pubic organizations' ability to effectively balance optimization and innovation (Gieske et al., 2020). There is a limited comprehensive study of ambidexterity in the public sector (Cannaerts et al., 2020; Palm \& Lilja, 2017; Smith \& Umans, 2015), or of how organizational ambidexterity is achieved and how it emerges in the public sector (Umans et al., 2018).

\section{Managers' Psychological Capital and Ambidexterity}

Ambidexterity is a multilevel phenomenon driven upward by individuals competing with a dynamic context (Good \& Michel, 2013). Its key manifestations, i.e., exploration and exploitation, originate at the individual level. Thus, studying ambidexterity at this level is a necessary precondition for understanding how individual's efforts form ambidexterity at the collective level of organizations (Keller \& Weibler, 2015). Researchers have highlighted individuals' critical role in producing ambidexterity at the organizational level and the individual abilities that help explain ambidextrous behaviors. Of course, studies on individuals' role in organizational ambidexterity have primarily focused on managers' behavioral characteristics (Good \& Michel, 2013).

Managers are essential antecedents to exploring and exploiting resources through their decisions and actions (Gibson \& Birkinshaw, 2004). Managers play a more significant role than environmental forces in determining organizational outcomes, especially in the digitalization (Velinov, Maly, Vojvodic, 2018). Therefore, managers' rationality and cognitions are reflected in their decisions and, consequently, in organizational outcomes (Smith \& Umans, 2015). Managers must recognize the need for ambidexterity in an organization based on their environmental dynamism and develop it using appropriate organizational characteristics. Although environmental dynamism cannot be managed, managers can design their organization's features (Pertusa-Ortega \& Molina-Azorín, 2018).

Gibson and Birkinshaw (2004) propose four ambidextrous behaviors: initiator, cooperator, broker, and multitasker. Initiators are alert to opportunities outside the boundaries of their jobs; cooperators seek opportunities to combine their efforts with others; brokers try to build internal relationships; and multitaskers can comfortably assume multiple roles in the organization. These behaviors are at the core of ambidexterity and explain how to create the dual structures that ensure alignment and adaptation at the individual level (Gibson \& Birkinshaw, 2004). Individual differences underpin ambidextrous behaviors, and as such, ambidexterity is likely a function of both individual and organizational effects (Kauppila \& Tempelaar, 2016; Raisch, Birkinshaw, Probst \& Tushman, 2009). Therefore, managers' characteristics, especially psychological traits, 
play a significant role in resolving paradoxical requirements and affect managers' ambidextrous behaviors. These characteristics are intangible but significantly affect how managers make a decision and confront different circumstances.

Certain individual traits can enhance personal capacity for effective action and play an essential role in goal-setting, motivation, success, and performance (Stajkovic, 2006). They characterize a wide range of psychological/behavioral processes and explain why some individuals, groups, or classes achieve better financial and social results than others. Luthans developed the theory of psychological capital to capture individual psychological capacities that can be measured, developed, and exploited for individual or organizational effectiveness (Newman, Schwarz, \& Borgia, 2013). The core construct of psychological capital emerged from positive psychology in general and from positive organizational behavior in particular (Luthans \& Youssef-Morgan, 2017) and places a higher weight on positive rather than negative aspects. Psychological capital is considered a promising psychological resource that influences various areas of one's life, including emotions, motivation, cognition, and behavior (Li, Castaño, \& Li, 2018) and affects employees' attitudes and work behaviors (Ardabili, 2020; Qiu, Yan, \& Lv, 2015; Voitenko, 2020).

An individual's innovative behaviors consist of complex behavioral tasks, including idea generation, idea promotion, and idea realization (Janssen, 2001). Research has shown that physiological capital components foster innovative behaviors in the workplace (Abbas \& Raja, 2015). Hopeful individuals look for alternative pathways when old ones are blocked (Snyder, 1994), actively work on creative ideas to solve problems, approach problems and opportunities from different angles (Zhou \& George, 2003), and show determination to overcome the risks and challenges of innovation failure. Optimists feel in control of their destiny and face problems and failures more calmly. They have positive expectations of themselves, and thus, achieving creative outcomes becomes self-fulfilling (Sweetman, Luthans, Avey, \& Luthans, 2011). Optimistic leaders pursue new and innovative problem-solving approaches (Peterson \& Byron, 2008).

The innovation process is complicated and uncertain, requiring employees to be intrinsically motivated to overcome challenges and setbacks and adapt to the changing environment. Resilient employees can persevere in a dynamic environment and can be creative in solving problems (Luthans, Youssef-Morgan \& Avolio, 2007). Employees need to possess high levels of selfconfidence and self-efficacy to thrive in such an environment (Rafiq, Wu, Chin, \& Nasir, 2019). Efficacious employees are more confident in their innovative ideas and are more willing to propose them in the workplace (Luthans et al., 2007). They are also more inventive, resourceful (Bandura, 1986), and creative (Tierney \& Farmer, 2002).

Psychological capital is a crucial factor affecting innovative behaviors in an organization (Luthans et al., 2007). Individuals with high psychological capital tend to exhibit creative behaviors and engage in idea generation, promotion, and realization in their work roles. Psychological capital plays a significant role in all the phases of innovation, including idea generation, idea support, and idea implementation. Individuals with high psychological capital are more likely to generate, acquire support for, and implement new ideas in the workplace (Abbas \& Raja, 2015). Psychological capital is an essential psychological resource that can be fostered and developed to energize and encourage employees to obtain competitive advantages, influencing their work state and outcomes. Individuals with high psychological capital are hopeful and optimistic in the face of difficulties and setbacks and continue to persevere and work hard without losing faith or giving up 
(Li et al., 2018). Psychological capital can be a predictor of managers' approach in dealing with conflicting decisions and balancing exploration and exploitation.

Therefore, by developing this capital, organizations can strengthen managers' capacity for ambidextrous behaviors. Moreover, studying the positive and negative effects of this intervention can help define a better positive reinforcement framework in human resource management.

\section{Methods}

Materials

In general, there are three approaches to qualitative content analysis: conventional, directed, and summative (Hsieh \& Shannon, 2005). The present study uses conventional content analysis. This inductive approach is used when existing theory or literature on a phenomenon is limited, and researchers allow categories to emerge from the data.

Elo and Kyngäs's (2008) content analysis method was employed, consisting of three phases: preparation, organizing, and reporting. In the preparation phase, the purpose of the research was established, and data were collected through interviews, each interview acting as a unit of analysis. Audio recordings were transcribed verbatim. The researcher and an expert in human resources with coding knowledge and experience conducted the organizing phase, including open coding, creating categories, and abstraction. Each interview transcript was read several times to gain a general understanding of its content. In the next step, sentences and words that responded to the research questions were identified as units of meaning and were coded into a categorization matrix using open coding. Extracted codes were compared, and similar codes were placed in one category, followed by categorization and abstraction of the results. Finally, the main themes were extracted. In the reporting phase, the final results were reported.

\section{Data Collection and Participants}

The participants were selected from university professors and lecturers in management and researchers in the area of organizational ambidexterity. We used the purposive sampling technique, and the sampling continued until data saturation. The participants were contacted by phone and/or e-mail to explain the purpose of the study and obtain informed consent. Due to the limited sample size and the participants' geographical dispersion, arrangements were made to conduct face-to-face interviews in the city and at the location where the participants felt comfortable. Moreover, the participants signed a consent form agreeing to the recording of the interviews. The ethical considerations of this research included obtaining informed consent for participation in the research, asking for permission to record the interviews, giving the participants freedom to withdraw from the research at any time, confirming interview transcripts with the participants, and maintaining privacy and confidentiality. Moreover, the participants were told that they would be informed of the final results of the study. We collected data through face-to-face semi-structured interviews. In each interview, the participants' demographic information was recorded, and then two open questions were asked: "What is your opinion on ambidexterity in the public sector? What is the role of managers and their psychological traits?" We asked follow-up questions to gain more insights into each of the issues discussed. Interviews lasted between 45 and 75 minutes. Out of the 13 anticipated interviews, two were canceled by the participants due to preoccupation despite their earlier agreement to participate and the researcher's presence in the agreed-upon location. Eleven interviews were conducted over five months, and saturation was reached at nine interviews. All participants were male with degrees in management and with at least one research paper on 
organizational ambidexterity. Data collection and data analysis were concurrent. Transcripts of interviews were reviewed several times by the researcher and the coding expert. We divided the transcripts into the smallest units of meaning for coding. The codes were also reviewed and classified into categories and subcategories based on similarities in meaning.

\section{Validity and Reliability of the Data}

To ensure the validity of the data, the participants were selected from those with knowledge and expertise in the subject. Also, the criteria proposed by Lincoln and Guba (1985) were used to ensure the reliability of the data, including credibility, dependability, transferability, and confirmability.

To enhance the credibility of the data, Beck's (1993) method was followed by having prolonged engagement with the data and devoting sufficient time to data collection and analysis. In addition, coding and data analysis lasted 12 months. As for dependability, the transcripts were reviewed by the participants. Consequently, the codes that did not reflect their views were adjusted (Lincoln, 1995). The coding stage was performed by the researcher and an expert in human resources with coding experience. Three coded transcripts were randomly selected and compared to ensure consistency in coding, and an $89 \%$ coder agreement was obtained. At the end of the coding process, the final results and codes were examined and validated by two management and psychology experts. Transferability indicates the degree to which the findings can be transferred and applied to other areas and contexts. To ensure transferability, detailed and "thick" descriptions of the context, characteristics of the participants, and the limitations of the research were provided to allow for generalization of the findings to other settings (Guba, 1981). As for confirmability, all the research stages were documented in detail so that other researchers who wish to continue research in this field can do so easily and based on documented interviews and analyses. Moreover, all the interviews were recorded, transcribed verbatim, and read several times to increase the descriptive validity of the research.

\section{Results and Discussion}

The purpose of this study was to identify the psychological traits of managers that contribute to ambidexterity in public organizations. As presented in Table 1, we identified one main theme, eight categories, 26 subcategories, and 101 codes resulting from semi-structured interviews with 11 participants. Eight psychological traits of managers of public organizations were found to affect their capacity for ambidexterity. These traits include courage, gratitude, spirituality, creativity, optimism, resilience, hope, and self-efficacy (see Table 1).

Table 1

Psychological Traits of Managers

\begin{tabular}{|l|l|l|l|}
\hline Main Theme & Categories & Subcategories & Codes \\
\hline \multirow{2}{*}{$\begin{array}{l}\text { Courage } \\
\text { Managers' } \\
\text { psychological } \\
\text { capital }\end{array}$} & Agility & $\begin{array}{l}\text { Responding quickly to changes } \\
\text { Agility during crises }\end{array}$ \\
\cline { 3 - 4 } & Risk-taking & $\begin{array}{l}\text { Taking responsibility for the external consequences of one's decisions } \\
\text { Ability to overcome internal barriers to one's decisions } \\
\text { Taking responsibility for one's mistakes } \\
\text { Risk appetite } \\
\text { Enjoying the implementation of risky plans }\end{array}$ \\
\cline { 2 - 4 } & Gratitude & $\begin{array}{l}\text { Showing gratitude to } \\
\text { subordinates }\end{array}$ & $\begin{array}{l}\text { Appreciating the efforts of subordinates } \\
\text { Feeling indebted to diligent and vulnerable employees } \\
\text { Commitment to encouraging and rewarding employees }\end{array}$ \\
& & & \\
& & & \\
\hline
\end{tabular}




\begin{tabular}{|c|c|c|}
\hline & $\begin{array}{l}\text { Financial and non- } \\
\text { financial rewards }\end{array}$ & $\begin{array}{l}\text { Compensating employees and allowing them to be creative } \\
\text { Motivating employees } \\
\text { Arranging an annual employee recognition event } \\
\text { Giving letters of commendation to employees } \\
\text { Following up on employee compensation } \\
\text { Showing constant appreciation and providing other non-financial rewards to } \\
\text { employees }\end{array}$ \\
\hline \multirow[t]{3}{*}{ Spirituality } & $\begin{array}{l}\text { Moral competencies } \\
\text { and virtues }\end{array}$ & $\begin{array}{l}\text { Being determined to eradicate corruption in public organizations } \\
\text { Treating everyone fairly } \\
\text { Commitment to respecting citizenship rights } \\
\text { Treating subordinates with respect and modesty } \\
\text { Adhering to fiduciary responsibilities } \\
\text { Promoting moral virtues among employees } \\
\text { Honesty } \\
\text { Empathizing with employees in hardships }\end{array}$ \\
\hline & Religious beliefs & $\begin{array}{l}\text { Alignment with newly adopted values and norms } \\
\text { Religious views }\end{array}$ \\
\hline & $\begin{array}{l}\text { Genuine commitment to } \\
\text { the organization }\end{array}$ & $\begin{array}{l}\text { Managers' sense of responsibility for their own job security and that of employees } \\
\text { Lack of attachment to the management position } \\
\text { Deriving inner peace from performing one's duties }\end{array}$ \\
\hline \multirow[t]{2}{*}{ Creativity } & $\begin{array}{l}\text { Creative behaviors in } \\
\text { daily tasks }\end{array}$ & $\begin{array}{l}\text { Applying novel approaches } \\
\text { Avoiding getting caught up in daily routines } \\
\text { Applying a variety of strategies and methods for running the organization } \\
\text { Taking initiative within the confines of their authority } \\
\text { Generating new ideas in the face of crisis } \\
\text { Reluctance to maintain the status quo } \\
\text { Creative decision making } \\
\text { Discovering new aspects of problems } \\
\text { Proposing unique solutions }\end{array}$ \\
\hline & $\begin{array}{l}\text { Promoting creativity } \\
\text { among employees }\end{array}$ & $\begin{array}{l}\text { Fostering a positive attitude toward creativity } \\
\text { Preventing employees from getting caught up in daily routines } \\
\text { Demonstrating concern for innovation and creativity }\end{array}$ \\
\hline \multirow{5}{*}{ Resilience } & $\begin{array}{l}\text { Identifying and } \\
\text { eliminating deficiencies }\end{array}$ & $\begin{array}{l}\text { Adapting to the organization's deficiencies } \\
\text { Moving toward filling existing gaps within the organization }\end{array}$ \\
\hline & $\begin{array}{l}\text { Ability to endure } \\
\text { hardships }\end{array}$ & $\begin{array}{l}\text { Emotional stability in stressful situations } \\
\text { Ability to reduce pressures from conflicting demands } \\
\text { Persevering at solving problems } \\
\text { Patience in dealing with unforeseen events } \\
\text { Ability to manage the organization under adverse conditions }\end{array}$ \\
\hline & $\begin{array}{l}\text { Managing conflicts } \\
\text { between employees }\end{array}$ & $\begin{array}{l}\text { Ability to manage employees' conflicting responses } \\
\text { Resilience against pressures from superiors }\end{array}$ \\
\hline & Ability to mitigate risks & Ability to solve everyday problems \\
\hline & and solve problems & Managing the short-term negative impacts of decisions \\
\hline \multirow{4}{*}{ Optimism } & $\begin{array}{l}\text { Building trust with } \\
\text { employees }\end{array}$ & $\begin{array}{l}\text { Building confidence and trust in superiors } \\
\text { Differentiating oneself from others in terms of performance } \\
\text { Continuous assessment of one's own performance } \\
\text { Self-esteem }\end{array}$ \\
\hline & $\begin{array}{l}\text { Interpreting events } \\
\text { positively }\end{array}$ & $\begin{array}{l}\text { Taking advantage of one's capabilities and capacities } \\
\text { Believing in the success of oneself and the organization } \\
\text { Self-confidence } \\
\text { Job satisfaction }\end{array}$ \\
\hline & $\begin{array}{l}\text { Focusing on the } \\
\text { positive aspects of } \\
\text { issues }\end{array}$ & $\begin{array}{l}\text { Spontaneous action } \\
\text { Self-motivation } \\
\text { Self-respect }\end{array}$ \\
\hline & $\begin{array}{l}\text { Thinking positively } \\
\text { about tasks }\end{array}$ & $\begin{array}{l}\text { Self-awareness } \\
\text { Diligence }\end{array}$ \\
\hline & Benchmarking & $\begin{array}{l}\text { Benchmarking against successful organizations } \\
\text { Implementing successful practices }\end{array}$ \\
\hline Hope & $\begin{array}{l}\text { Goal-setting and } \\
\text { planning }\end{array}$ & $\begin{array}{l}\text { Setting goals and objectives } \\
\text { Emphasizing on individual planning } \\
\text { Being proactive and not reactive }\end{array}$ \\
\hline
\end{tabular}




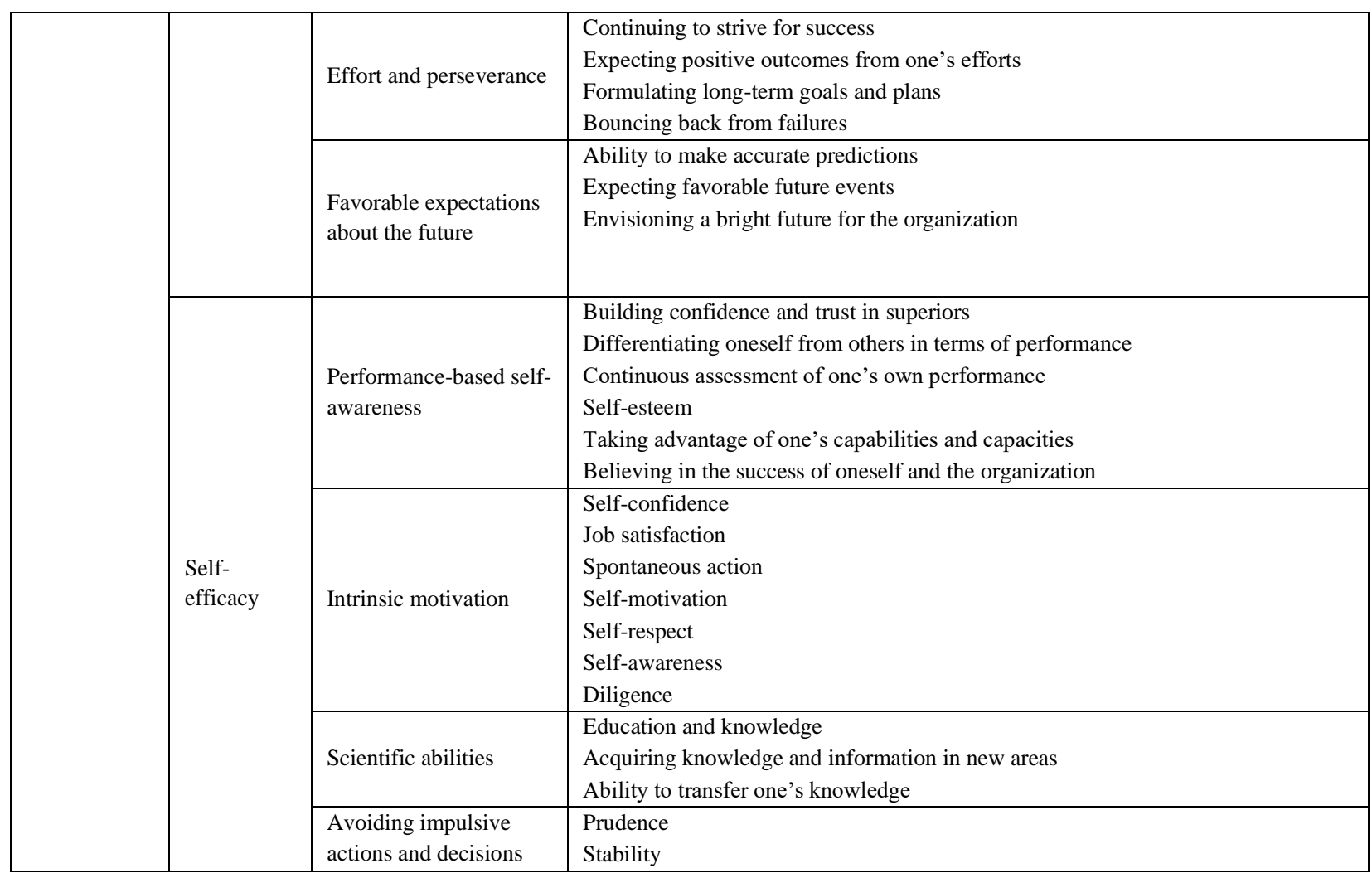

\section{Courage}

Courage is one of the most prominent psychological traits of managers. Based on the present findings, it can be classified into two categories, namely, agility and risk-taking. Consistent with Luthans and Youssef-Morgan (2017) and Luthans, Youssef-Morgan and Avolio (2015), courage is considered a potential psychological capital. Courage has been highlighted as a management virtue (Srivastva \& Cooperrider, 1998), and influential leaders promote courage in the organization through their complex behaviors (Denison, Hooijberg, \& Quinn, 1995). Moral courage is a key behavioral competency for managers, enabling them not to hesitate to do the right thing in the face of threats and risks and show courage in emergencies (Darley \& Latane, 1968). Courageous managers can make quick and correct decisions in critical and risky situations, leading the organization in innovative activities and helping it explore and take advantage of new opportunities.

According to Adiwijaya, Wahyuni, Gayatri, and Mussre (2020), organizations that wish to develop their marketing exploration capabilities must support the management team to establish bold marketing processes. On the other hand, accountability, discipline, obedience, and predictability are often valued in bureaucracies. However, these values do not serve the organization well during turmoil and revolutionary change. In such an organizational climate, innovators and change agents must be courageous to effectively communicate their ideas and perspectives (Worline \& Quinn, 2003). Courage requires character strength and the willingness to overcome threats in pursuit of the right action (Sekerka \& Bagozzi, 2007). Tensions arising from ambidexterity, especially as it relates to exploration and innovation, pose several threats to the organization, especially in the public sector, where managers must confront resistance with courage and pave the way for the implementation of ambidextrous strategies. These threats are not necessarily external. Pressures from organizational rules and bureaucracy to comply and maintain the status quo also threaten efforts toward ambidexterity. Managers with a high level of courage 
have a higher tendency for ambidextrous behaviors, while their exploratory ideas will not be realized without courage.

Due to their nature and purpose, public organizations need managers who remain courageous and ethical in their decision making in the face of various threats and even the risk of losing certain privileges). This trait helps managers overcome the threats and risks of decisions relating to the implementation and continuation of ambidexterity and helps the organization become ambidextrous. Darley and Latane (1968) argue that civil courage entails exhibiting altruistic, prosocial, and normative behaviors in emergency situations, and courageous managers who assess the future of the organization to be grim do not stand by, propose risky solutions, can implement them, and are not afraid of failure or resistance. Therefore, courage is a trait that is much sought after and is crucial to achieving organizational ambidexterity and succeeding in exploration activities.

\section{Gratitude}

According to the participants, gratitude is another key psychological trait for managers. This trait is classified into two subcategories: the appreciation of the subordinates and financial and nonfinancial rewards. The present findings are consistent with the results of other studies that consider gratitude a potential psychological capital (Luthans \& Youssef-Morgan, 2017; Luthans et al., 2015). Similarly, Komter (2004) argues that gratitude is essential for creating and maintaining positive human relationships and finds that individuals with higher scores on the Gratitude Questionnaire are expected to better adapt to their environment. Managers' inner commitment to recognize employees' contributions strengthens their relationship and increases the ability of employees to adapt to ambidexterity, encourages them to participate in ambidextrous and innovative activities, and reduces resistance to such initiatives. Recognizing employees' performance is the driving force that motivates them to exert more effort and achieve higher efficiency and productivity, thus improving the exploitation aspect of ambidexterity.

According to Jansen et al. (2008), contingency rewards are associated with an organization's ability to combine exploration and exploitation and play a positive role in achieving organizational ambidexterity. Individual creative behavior has been linked to personal characteristics such as personality and motivation (Woodman, Sawyer, \& Griffin, 1993). Financial and non-financial rewards can serve as a motivating factor for better performance, encourage employees to perform challenging and complex tasks, and reinforce ambidextrous tendencies. Employees will know that their contributions to the organization's exploration and exploitation are appreciated by the management that will strengthen their determination, motivation, and cooperation to realize organizational ambidexterity.

\section{Spirituality}

The third key psychological trait is managers' spirituality. Spirituality has been recognized as a potential psychological resource (Luthans et al., 2015; Luthans \& Youssef-Morgan, 2017). Based on the present findings, spirituality is classified into three subcategories: moral competencies and virtues, religious beliefs, and genuine commitment to the organization. Spirituality plays a significant role in effective coping processes (Pargament, 1997). In addition, a positive relationship has been observed between spirituality and work unit performance in hospitals (Duchon \& Plowman, 2005), employee performance and employee efficiency and productivity. Spiritual managers respect customers and treat employees fairly (Ibrahim, Rue, McDougall, \& Greene, 
1991). Spirituality promotes the spirit of serving customers and society as well as ethical behaviors in the organization. Spiritual employees strive to serve humanity and future generations and tend to deal with the problems with more significant effort and commitment. This trait can be crucial to effective exploration and exploitation in ambidextrous organizations.

According to Brown and Gioia (2002), spiritual leaders can be more effective in managing the organization and achieving its goals and vision. Organizational spirituality consists of two dimensions, i.e., work and management, through which managers can improve workplace productivity and increase organizational efficiency (Abdi, Chaib, \& Verzea, 2020). Spirituality enables managers to face uncertainties and risks with composure and effectively deal with changes in today's complex world. Therefore, strengthening spirituality is likely to have a positive effect on organizational ambidexterity. Spiritual support enables individuals to withstand stressful situations (Yang \& Mao, 2007), and strong religious beliefs help individuals become immune to stress (Graham, Furr, Flowers, \& Burke, 2001). By providing spiritual support and planting the seeds of faith in employees, spiritual managers can help them cope with stressful activities such as innovation and exploration, thus enabling the organization to pursue such activities and achieve ambidexterity.

\section{Creativity}

Creativity is a potential psychological resource in individuals and managers (Luthans et al., 2015; Luthans \& Youssef-Morgan, 2017). According to the interviews, managers' creativity can be classified into two subcategories: creative behaviors in daily tasks and promoting creativity among employees. Palm and Lilja (2017) found that creativity is one of the significant enabling factors for organizational ambidexterity in the public sector. Creativity is associated with thinking outside the box, experimenting, and going beyond typical routines and assumptions, which are critical to explorative activities and ambidexterity (Schindler, 2015). Highly creative individuals can generate new ideas and be assigned to explorative tasks to create new opportunities. They bring fresh and unpredictable ideas and provide a valuable competitive advantage for the organization. In changing environments, employees with high levels of creativity tend to explore and innovate and play a key role in achieving organizational ambidexterity. Creative individuals are resilient to negative feedback and look for new and innovative solutions to problems and challenges with a high degree of self-confidence. These individuals challenge the status quo and bring about change and create new opportunities for a better future by providing new solutions for simple and complex problems. They form the organization's innovation and exploration units and play a key role in transforming it into an ambidextrous organization.

\section{Resilience}

Resilience was also found to be a key psychological resource consistent with previous studies (Avey, Patera \& West, 2006; Avey, Wernsing \& Luthans, 2008; Costantini et al., 2017; Li et al., 2018; Luthans et al., 2007; Luthans et al., 2015; Luthans, Vogelgesang \& Lester, 2006; Luthans \& Youssef-Morgan, 2007; Luthans \& Youssef-Morgan, 2017). According to the participants, resilience consists of four subcategories: identifying and eliminating deficiencies, ability to endure hardships, managing conflicts between employees, and ability to mitigate risks and solve problems.

Resilient individuals have strong problem-solving skills (Jew, Green, \& Kroger, 1999), cope well with adversities (Bonanno, 2004), and are creative thinkers (Bogar \& Hulse-Killacky, 2006). Resilience allows individuals to recover from setbacks and even turn them into opportunities for 
growth. Resilient individuals are capable of adapting to adverse situations (Weiss, 2008), avoiding confusion (Wolin \& Wolin, 1993), and recognizing deficiencies in implementing a plan. Therefore, they can enable organizations to avoid potential risks and use their creative thinking and problemsolving skills to propose necessary solutions in implementing ambidexterity. Resilient individuals view problems and threats as opportunities that can be exploited to help the organization achieve greater success. They do not back down when faced with obstacles, bounce back from failure, and persevere and thrive in adverse situations, which are important qualities for an ambidextrous organization.

Resilient individuals can always overcome challenges and identify new opportunities (Richtnér $\&$ Löfsten, 2014) and can successfully adapt to and overcome adverse circumstances (Hawley, 2000). Resilient managers build positive relationships with others (Bonanno, 2004), treat others with empathy (Jew et al., 1999), and promote cooperation. They boost employee morale and encourage them to treat problems as temporary obstacles to bounce back from and continue to the finish line. This support from managers increases employees' interest in and enthusiasm for exploratory and innovative tasks, which encourages them to spend more time to achieve results in these activities and puts the organization on a relatively easy path to becoming ambidextrous.

\section{Optimism}

Optimism is one of the four key dimensions of psychological capital (Avey et al., 2006; Avey et al., 2008; Li et al., 2018; Luthans et al., 2006; Luthans et al., 2007; Luthans et al., 2015; Luthans \& Youssef-Morgan, 2007; Luthans \& Youssef-Morgan, 2017) and one of three psychological capacities in positive leadership (Greenberg \& Arakawa, 2008). According to this research participants, managers' optimism can be classified into four subcategories: building trust with employees, interpreting events positively, focusing on the positive aspects of issues, and thinking positively about tasks.

Optimism increases a person's ability to endure situations (Seligman, 1998). Optimists keep pursuing their goals in the face of adversity (Scheier, Carver, \& Bridges, 1994) and have a sense of control over events. Optimistic employees try to understand how the organization operates and monitor its operation and performance to respond to changes (Chiu, Harry Hui, \& Lai, 2007). Therefore, by understanding the need for improving short-term and long-term performance, optimists will develop a positive outlook about the results and consequences of organizational ambidexterity and deal with its problems with a positive approach. Optimistic managers are critical to the successful implementation of ambidexterity. Through constructive interaction and positivity, managers can help employees be steadier in their pursuit of goals and position the organization on the path toward ambidexterity. Optimism can also lead managers to positively interpret the organizational and environmental pressures of ambidexterity and prevent them from being transferred to employees.

Optimism represents a vital lesson in self-discipline, analysis of past events, contingency planning, and prevention. It helps both the employees and managers to go beyond predictions and improve their chances in the future. Optimists welcome change, consider future opportunities and capitalize on these opportunities. Optimistic leaders are risk-takers. They are more effective interpersonally and make better decisions due to their superior ability to collect and use the information and identify and respond to situational contingencies (Luthans et al., 2015). These qualities are aligned with the exploration component of ambidexterity and support the implementation of ambidextrous strategies. 


\section{Hope}

Consistent with previous studies (e.g., Berg \& Heidbrink, 2017; Grobler \& Joubert, 2018; Luthans et al., 2015; Luthans \& Youssef-Morgan, 2017), hope is identified in the present research as a critical component of psychological capital. Given that this study focuses on ambidexterity in public organizations, the participants classified this trait into the following four subcategories: benchmarking, goal-setting and planning, effort and perseverance, and favorable expectations about the future.

Hope is difficult to emulate by competitors, and thus it is a source of sustainable competitive advantage (Snyder, 1994). Hope is defined as the perceived ability to produce pathways to achieve desired goals and motivate oneself to use those pathways (Snyder, 1994). High levels of hope can improve an individual's performance and help them move up to the next stages of a given pathway. Peterson and Byron (2008) found that employees and executives with higher hopes develop more and better solutions for work-related problems. These are diligent individuals who set various goals, including short-term goals and use multiple pathways to accomplish them. They persist at completing their daily tasks and are a valuable resource for improving the exploitation component of ambidexterity.

According to Luthans et al. (2015), hopeful leaders are effective planners who can set specific, challenging goals and align them to the most critical organizational objectives. They simulate others, reward creative pathways, and possess energy and determination that can trickle down to their followers, motivating them to achieve better performance. Today, organizations must take advantage of growing the hope of their workforce to remain at the top of the innovation and productivity curve. Individuals with high levels of hope can derive new or alternative pathways for goal achievement when faced with obstacles and have more consistent emotional responses. They pursue alternative goals when the main goal is not achievable. Hopeful managers set challenging goals with determination and energy and align them to organizational goals. They use financial and non-financial rewards to stimulate employees and prevent resistance and hindrance along the pathways for achieving these goals. Organizational ambidexterity is one such challenging goal that can benefit from hope since hopeful individuals pursue alternative pathways to attain goals if the original pathway is blocked and tend to be creative and resourceful even with limited budgets (Luthans et al., 2015). Hopeful managers fight to attain goals since they expect to succeed and can be significant assets in innovative and exploratory activities crucial for achieving organizational ambidexterity.

\section{Self-efficacy}

Self-efficacy is a crucial component of psychological capital (Avey et al., 2008; Berg \& Heidbrink, 2017; Costantini et al., 2017; Grobler \& Joubert, 2018; Li et al., 2018; Luthans et al., 2015; Luthans \& Youssef-Morgan, 2017) and is identified in the present research as one of the psychological traits that affect managers' ambidexterity. The participants classified self-efficacy into four subcategories: performance-based self-awareness, intrinsic motivation, scientific ability, and avoiding impulsive actions and decisions.

Self-efficacy is the most widely studied component of psychological capital in individual ambidexterity literature. This trait has been discussed as a critical antecedent for ambidexterity. According to Van Baarlen (2018), managers' self-efficacy beliefs are positively associated with exploration and exploitation and can be an essential antecedent for ambidextrous behavior. 
Similarly, Yu, Gudergan, and Chen (2018) argue that self-efficacy improves behavioral predictions due to its direct or indirect effect on behavior and is positively associated with ambidexterity in frontline employees. Managers with high self-efficacy have confidence in their abilities, which leads them to strive for progress and success, welcome responsibilities and difficult tasks, and engage in both explorative and exploitative activities.

General self-efficacy motivates individuals to pursue ambidextrous behavior (Kauppila \& Tempelaar, 2016). Self-efficacious managers compare their performance with others and seek to improve it, which improves organizational performance and the exploitation component of ambidexterity. Moreover, they are intrinsically motivated to perform creative tasks. Based on their self-assessment and the feedback they receive about the results of their activities, they try to create new opportunities for the organization, thus strengthening the exploration component of ambidexterity.

\section{Conclusion}

Public organizations are continually facing new challenges that are impossible to overcome with conventional, bureaucratic approaches. The COVID-19 pandemic is a tangible example and has challenged all organizations, especially those in the public sector, with conflicting and inconsistent demands. Ambidexterity can help organizations navigate through these crises and other similar circumstances. Managers play a crucial role in organizational ambidexterity. Organizations can try to capitalize on their managers' and employees' psychological capacities and potentials instead of structural and/or regulatory changes that are more costly and time-consuming.

Psychological traits such as courage, gratitude, spirituality, creativity, resilience, optimism, hope, and self-efficacy underpin ambidextrous behavior in managers and, as a whole, form the higher-level construct of psychological capital, which is crucial to the success of organizations. Public organizations must identify and evaluate different components of psychological capital in their managers and employees and implement short-term and long-term programs to develop them. These organizations must also review the process for filling management positions and make psychological capital a determining factor in the recruitment, selection, and appointment of managers. This will ensure that organizations take full advantage of their psychological capital and pave the way to achieve organizational ambidexterity.

Although the flexibility of content analysis has made it useful for various research types, the lack of a firm definition and procedure can limit its application (Tesch, 1990). There are no systematic rules for analyzing data (Elo \& Kyngäs, 2007). As a result, similar studies may reach different conclusions.

\section{References}

Abbas, M., \& Raja, U. (2015). Impact of psychological capital on innovative performance and job stress. Canadian Journal of Administrative Sciences/Revue Canadienne des Sciences de l'Administration, 32(2), 128-138. https://doi.org/10.1002/CJAS.1314

Adiwijaya, K., Wahyuni, S., Gayatri, G., \& Mussry, J. S. (2020). Does marketing ambidexterity boost marketing performance? Empirical evidence in Indonesia's consumer goods. Journal of Global Marketing, 33(4), $266-288$. https://doi.org/10.1080/08911762.2019.1696438 
Ardabili, F. S. (2020). Moderating-mediating effects of leader member exchange, self-efficacy and psychological empowerment on work outcomes among nurses. Organizacija, 53(3), 246-258. https://doi.org/10.2478/orga-2020-0016

Avey, J. B., Patera, J. L., \& West, B. J. (2006). The implications of positive psychological capital on employee absenteeism. Journal of Leadership and Organizational Studies, 13(2), 42-60. https://doi.org/10.1177/10717919070130020401

Avey, J. B., Wernsing, T. S., \& Luthans, F. (2008). Can positive employees help positive organizational change? Impact of psychological capital and emotions on relevant attitudes and behaviors. The Journal of Applied Behavioral Science, 44(1), 4870. https://doi.org/10.1177/0021886307311470

Bandura, A. (1986). Social foundations of thought and action. Englewood Cliffs, NJ, 23-28.

Beck, C. T. (1993). Qualitative research: The evaluation of its credibility, fittingness, and auditability. Western Journal of Nursing Research, 15(2), 263-266. https://doi.org/10.1177/019394599301500212

Berg, V., \& Heidbrink, M. (2017). Comparison of the psychological capital of founders and their employed top management. Journal of Psychology and Clinical Psychiatry, 8(3), 00482. https://doi.org/10.15406/jpcpy.2017.08.00482

-Birkinshaw, J., \& Gupta, K. (2013). Clarifying the distinctive contribution of ambidexterity to the field of organization studies. Academy of Management Perspectives, 27(4), 287-298. https://doi.org/10.5465/amp.2012.0167

Bogar, C. B., \& Hulse-Killacky, D. (2006). Resiliency determinants and resiliency processes among female adult survivors of childhood sexual abuse. Journal of Counseling and Development, 84, 318-327. https://doi.org/10.1002/j.15566678.2006.tb00411.x

Bonanno, G. A. (2004). Loss, trauma, and human resilience: Have we underestimated the human capacity to thrive after extremely aversive events? American Psychologist, 59(1), 20-28. https://doi.org/10.1037/0003-066X.59.1.20

Brown, M. E., \& Gioia, D. A. (2002). Making things click: Distributive leadership in an online division of an offline organization. The Leadership Quarterly, 13(4), 397-419. https://doi.org/10.1016/S1048-9843(02)00123-6

Bruns, T., \& Stalker, G. M. (1961). The management of innovation. Tavistock, London, 120-122.

Bryson, J. M., Boal, K. B., \& Rainey, H. G. (2008). Strategic orientation and ambidextrous public organizations. Paper presented at the Conference on Organisational Strategy, Structure and Process: A Reflection on the Research Perspective of Raymond Miles and Charles Snow, Cardiff University.

Cannaerts, N., Segers, J., \& Henderickx, E. (2016). Ambidextrous design and public organizations: a comparative case study. International Journal of Public Sector Management, 29(7), 708-724. https://doi.org/10.1108/IJPSM-12-2015-0210

Cannaerts, N., Segers, J., \& Warsen, R. (2020). Ambidexterity and public organizations: A configurational perspective. Public Performance and Management Review, 43(3), 688-712. https://doi.org/10.1080/15309576.2019.1676272

Chiu, W. C., Harry Hui, C., \& Lai, G. W. (2007). Psychological ownership and organizational optimism amid China's corporate transformation: Effects of an employee ownership scheme and a management-dominated board. The International Journal of Human Resource Management, 18(2), 303-320. https://doi.org/10.1080/09585190601102539

Chng, W. Y., \& Le Huy, N. H. (2019). Organizational ambidexterity: How space companies can balance exploitation and exploration to compete successfully in the launch business. Toulouse Business School Professional Option - Aerospace Management.

Costantini, A., De Paola, F., Ceschi, A., Sartori, R., Meneghini, A. M., \& Di Fabio, A. (2017). Work engagement and psychological capital in the Italian public administration: A new resource-based intervention programme. SA Journal of Industrial Psychology, 43(1), 1-11. http://dx.doi.org/10.4102/sajip.v43i0.1413

Cunningham, J. B., \& Kempling, J. S. (2009). Implementing change in public sector organizations. Management decision, 47(2), 330-344. https://doi.org/10.1108/00251740910938948

Darley, J. M., \& Latane, B. (1968). Bystander intervention in emergencies: Diffusion of responsibility. Journal of Personality and Social Psychology, 8(4, Pt.1), 377-383. https://doi.org/10.1037/h0025589

Denison, D. R., Hooijberg, R., \& Quinn, R. E. (1995). Paradox and performance: Toward a theory of behavioral complexity in managerial leadership. Organization Science, 6(5), 524-540. https://doi.org/10.1287/orsc.6.5.524

Duchon, D., \& Plowman, D. A. (2005). Nurturing the spirit at work: Impact on work unit performance. Leadership Quarterly, 16(5), 807-834. https://doi.org/10.1016/j.leaqua.2005.07.008

Duncan, R. B. (1976). The ambidextrous organization: Designing dual structures for innovation. The Management of Organization, 1(1), 167-188.

Elo, S., \& Kyngäs, H. (2008). The qualitative content analysis process. Journal of Advanced Nursing, 62(1), 107-115. https://doi.org/10.1111/j.1365-2648.2007.04569.x

Gibson, C. B., \& Birkinshaw, J. (2004). The antecedents, consequences, and mediating role of organizational ambidexterity. Academy of Management Journal, 47(2), 209-226. https://doi.org/10.5465/20159573

Gieske, H., George, B., van Meerkerk, I., \& van Buuren, A. (2020). Innovating and optmizing in public organizations: Does more become less? Public Management Review, 22(4), 475-497. http://doi.org/10.1080/14719037.2019.1588356 
Good, D., \& Michel, E. J. (2013). Individual ambidexterity: Exploring and exploiting in dynamic contexts. The Journal of psychology, 147(5), 435-453. https://doi.org/10.1080/00223980.2012.710663

Graham, S., Furr, S., Flowers, C., \& Burke, M. T. (2001). Religion and spirituality in coping with stress. Counselling and Values, 46(1), 2-13. https://doi.org/10.1002/j.2161-007X.2001.tb00202.x

Greenberg, M. H., \& Arakawa, D. R. (2008). Optimistic managers and their influence on productivity and employee engagement in a technology organization. Master of Applied Positive Psychology (MAPP) Capstone Projects, 1-15. http://repository.upenn.edu/mapp_capstone/49

Grobler, A., \& Joubert, Y. T. (2018). Psychological Capital: Convergent and discriminant validity of a reconfigured measure. South African Journal of Economic and Management Sciences, 21(1), 1-14. http://dx.doi.org/10.4102/sajems.v21i1.1715

Guba, E. G. (1981). Criteria for assessing the trustworthiness of naturalistic inquiries. Educational Communication and Technology Journal, 29(2), 75-91. https://doi.org/10.1007/BF02766777

Hartley, J. (2005). Innovation in governance and public services: Past and present. Public Money and Management, 25(1), 27-34. http://doi.org/10.1111/j.1467-9302.2005.00447.x

Hawley, D. R. (2000). Clinical implications of family resilience. The American Journal of Family Therapy, 28(2), 101-116. https://doi.org/10.1080/019261800261699

Hsieh, H. F., \& Shannon, S. E. (2005). Three approaches to qualitative content analysis. Qualitative Health Research, 15(9), 1277-1288. https://doi.org/10.1177/1049732305276687

Ibrahim, N. A., Rue, L. W., McDougall, P. P., \& Greene, G. R. (1991). Characteristic and practice of Christian based companies. Journal of Business Ethics, 10(2), 132-123. https://doi.org/10.1007/BF00383615

Jansen, J. J., George, G., Van den Bosch, F. A., \& Volberda, H. W. (2008). Senior team attributes and organizational ambidexterity: The moderating role of transformational leadership. Journal of Management Studies, 45(5), 982-1007. https://doi.org/10.1111/j.1467-6486.2008.00775.x

Janssen, O. (2001). Fairness perceptions as a moderator in the curvilinear relationships between job demands, and job performance and job satisfaction. Academy of Management Journal, 44(5), 1039-1050. https://doi.org/10.5465/3069447

Jew, C., Green, K., \& Kroger, J. (1999). Development and validation of a measure of resiliency. Measurement and Evaluation in Counseling and Development, 32(2), 75-89. https://doi.org/10.1080/07481756.1999.12068973

Kauppila, O. P., \& Tempelaar, M. P. (2016). The social-cognitive underpinnings of employees' ambidextrous behaviour and the supportive role of group managers' leadership. Journal of Management Studies, 53(6), 1019-1044. https://doi.org/10.1111/joms.12192

Keller, T., \& Weibler, J. (2015). What it takes and costs to be an ambidextrous manager: Linking leadership and cognitive strain to balancing exploration and exploitation. Journal of Leadership and Organizational Studies, 22(1), 54-71. https://doi.org/10.1177/1548051814524598

Kobarg, S., Wollersheim, J., Welpe, I. M., \& Spörrle, M. (2017). Individual ambidexterity and performance in the public sector: A multilevel analysis. International Public Management Journal, 20(2), 226-260. https://doi.org/10.1080/10967494.2015.1129379

Komter, A. E. (2004). Gratitude and gift exchange. The Psychology of Gratitude, 195212.

Laureiro-Martinez, D., Brusoni, S., \& Zollo, M. (2010). The neuroscientific foundations of the exploration-exploitation dilemma. Journal of Neuroscience, Psychology, and Economics, 3(2), 95-115. https://doi.org/10.1037/a0018495

Lawrence, P. R., \& Lorsch, J. W. (1967). Differentiation and integration in complex organizations. Administrative Science Quarterly, 1-47.

Lee, S. M., Hwang, T., \& Choi, D. (2012). Open innovation in the public sector of leading countries. Management Decision, 50(1), 147-162. https://doi.org/10.1108/00251741211194921

Levinthal, D. A., \& March, J. G. (1993). The myopia of learning. Strategic Management Journal, 14, 95-112. https://doi.org/10.1002/smj.4250141009

Li, Y., Castaño, G., \& Li, Y. (2018). Linking leadership styles to work engagement. Chinese Management Studies. International Public Management Journal, 20(2), 226-260. https://doi.org/10.1108/CMS-04-2017-0108

Lincoln, Y. S. (1995). Emerging criteria for quality in qualitative and interpretive research. Qualitative Inquiry, 1(3), $275-289$. https://doi.org/10.1177/107780049500100301

Lincoln, Y. S., \& Guba, E. G. (1985). Establishing trustworthiness. Naturalistic Inquiry, 289(331), 289-327.

Lis, A., Józefowicz, B., Tomanek, M., \& Gulak-Lipka, P. (2018). The concept of the ambidextrous organization: Systematic literature review. International Journal of Contemporary Management, 17(1), $77-97$. https://doi.org/10.4467/24498939IJCM.18.005.8384

Luthans, F., Vogelgesang, G. R., \& Lester, P. B., (2006). Developing the psychological capital of resiliency. Human Resource Development Review, 5(1), 25-44. https://doi.org/10.1177/1534484305285335 
Luthans, F., \& Youssef-Morgan, C. M. (2007). Emerging positive organizational behavior. Journal of Management, 33(3), 321349. https://doi.org/10.1177/0149206307300814

Luthans, F., \& Youssef-Morgan, C. M. (2017). Psychological capital: An evidence-based positive approach. Annual Review of Organizational Psychology and Organizational Behavior, 4, 339-366. https://doi.org/10.1146/annurev-orgpsych-032516113324

Luthans, F., Youssef-Morgan, C. M., \& Avolio, B. J. (2007). Psychological capital: Developing the human Competitive edge. Oxford, UK: Sage.

Luthans F, Youssef-Morgan C. M, Avolio B. (2015). Psychological capital and beyond. New York: Oxford Univ. Press

Maclean, M., Harvey, C., Golant, B. D., \& Sillince, J. A. (2020). The role of innovation narratives in accomplishing organizational ambidexterity. Strategic Organization, https://doi.org/10.1177 /1476127019897234

Maier, J. (2015). The ambidextrous organization: Exploring the new while exploiting the now. Springer.

March, J. G. (1991). Exploration and exploitation in organizational learning. Organization Science, $2(1)$, 71-87. https://doi.org/10.1287/orsc.2.1.71

March, J. G., \& Simon, H. A. (1958). Organizations. New York: Wiley.

Newman, A., Schwarz, S., \& Borgia, D. (2013). How does microfinance enhance entrepreneurial outcomes in emerging economies? The mediating mechanisms of psychological and social capital. International Small Business Journal, 32(2), 158179. https://doi.org/10.1177/0266242613485611

O'Reilly, C. A., \& Tushman, M. L. (2004). The ambidextrous organization. Harvard Business Review, 82(4), 74-81.

Osborne, S. P., \& L. Brown. (2011). Innovation, public policy and public services delivery in the UK. The word that would be king? Public Administration, 89(4), 1335-1350. http://doi.org/10.1111/padm.2011.89.

Palm, K., \& Lilja, J. (2017). Key enabling factors for organizational ambidexterity in the public sector. International Journal of Quality and Service Sciences, 9(1), 2-20. http://dx.doi.org/10.1108/IJQSS-04-2016-0038

Pargament, K. (1997). The psychology of religion and coping: Theory, research, and practice. New York, NY: Guilford Press.

Pertusa-Ortega, E. M., \& Molina-Azorín, J. F. (2018). A joint analysis of determinants and performance consequences of ambidexterity. BRQ Business Research Quarterly, 21(2), 84-98. https://doi.org/10.1016/j.brq.2018.03.001

Peterson, S. J., \& Byron, K. (2008). Exploring the role of hope in job performance: Results from four studies. Journal of Organizational Behavior, 29(6), 785-803. https://doi.org/10.1002/job.492

Qiu, X. W., Yan, X. C., \& Lv, Y. L. (2015). The effect of psychological capital and knowledge sharing on innovation performance for professional technical employees. Journal of Service Science and Management, 8(4), 545-551. https://doi.org/10.4236/jssm.2015.84055

Rafiq, M., Weiwei, W., Chin, T., \& Nasir, M. (2019). The moderating effect of career stage on the relationship between job embeddedness and innovation-related behaviour (IRB) evidence from China. World Journal of Entrepreneurship, Management Sustainable Development, 15, 109-122. http://dx.doi.org/10.1108/WJEMSD-04-2018-0045.

Raisch, S., Birkinshaw, J., Probst, G., \& Tushman, M. L. (2009). Organizational ambidexterity: Balancing exploitation and exploration for sustained performance. Organization Science, 20(4), 685-695. https://doi.org/10.1287/orsc.1090.0428

Richtnér, A., \& Löfsten, H. (2014). Managing in turbulence: how the capacity for resilience influences creativity. $R \& D$ Management, 44(2), 137-151. https://doi.org/10.1111/radm.12050

Scheier, M. F., Carver, C. S., \& Bridges, M. W. (1994). Distinguishing optimism from neuroticism (and trait anxiety, self-mastery, and self-esteem): A reevaluation of the life orientation test. Journal of Personality and Social Psychology, 67(6), 1063-1078. http://doi.org/10.1037//0022-3514.67.6.1063

Schindler, A. (2015). Ambidextrous Leadership: the role of flexibly switching between opening and closing leadership behaviors for team innovative outcome in the case of management consultancies (Unpublished master's thesis) University of Twente.

Sekerka, L. E., \& Bagozzi, R. P. (2007). Moral courage in the workplace: Moving to and from the desire and decision to act. Business Ethics: A European Review, 16(2), 132-149. https://doi.org/10.1111/j.1467-8608.2007.00484.x

Seligman, M. (1998). Learned optimism: How to change your mind and your life. New York: pocket Books.

Simsek, Z., Heavey, C., Veiga, J. F., \& Souder, D. (2009). A typology for aligning organizational ambidexterity's conceptualizations, antecedents, and outcomes. Journal of Management Studies, 46(5), 864-894. http://doi.org/10.1111/j.14676486.2009.00841.x

Smith, E., \& Umans, T. (2015). Organizational ambidexterity at the local government level: The effects of managerial focus. Public Management Review, 17(6), 812-833. https://doi.org/10.1080/14719037.2013.849292

Snyder, C. R. (1994). The psychological of hope: You can get there from here. New York: Free Press.

Srivastva, S., \& Cooperrider, D. L. (1998). Organizational wisdom and executive courage. San Francisco, CA: The New Lexington Press, Lexington Books. 
Stajkovic, A. D. (2006). Development of a core confidence-higher order construct. Journal of Applied. Psychology, 91(6), 12081224. https://doi.org/10.1037/0021-9010.91.6.1208

Sweetman, D., Luthans, F., Avey, J., \& Luthans, B. (2011). Relationship between positive psychological capital and creative performance. Canadian Journal of Administrative Sciences, 28(1), 4-13. http://dx.doi.org/10.1002/CJAS.175

Tesch, R. (1990). Qualitative research: Analysis types and software tools. Bristol, PA: Falmer.

Tierney, P., \& Farmer, S. M. (2002). Creative self-efficacy: Potential antecedents and relationship to creative performance. Academy of Management Journal, 45(6), 1137-1148. https://doi.org/10.5465/3069429

Turner, N., \& Lee-Kelley, L. (2013). Unpacking the theory on ambidexterity: An illustrative case on the managerial architectures, mechanisms and dynamics. Management Learning, 44(2), 179-196. https://doi.org/10.1177/1350507612444074

Umans, T., Smith, E., Andersson, W., \& Planken, W. (2018). Top management teams' shared leadership and ambidexterity: The role of management control systems. International Review of Administrative Sciences, 86(3), 444-462, http://dx.doi.org/10.1177/0020852318783539

Van Baarlen, D. E. N. N. I. S. (2018). Middle managers' ambidexterity: A social cognitive perspective on ambidextrous behavior (Unpublished master's thesis). Rotterdam School of Management (RSM), Erasmus University.

Velinov, E., Maly, M., \& Vojvodic, M. (2018). Digitalization on boards: Evidence from the Baltic public listed companies. Management and Business Research Quarterly, 6, 10-15. https://doi.org/10.32038/mbrq.2018.06.02

Voitenko, E. (2020). Emotional burnout as a result of professional stress in the work of managers. Behavior Studies in Organizations, 3, 5-12. https://doi.org/10.32038/JBSO.2020.03.02

Weiss, L. G. (2008). Toward the mastery of resiliency. Canadian Journal of School Psychology, 23(1), 127-137. https://doi.org/10.1177/0829573508316600

Wolin, S. J., \& Wolin, S. (1993). The resilient self: How survivors of troubled families rise above adversity. New York: Villard Books.

Woodman, R. W., Sawyer, J. E. \& Griffin, R. W. (1993). Toward a theory of organizational creativity. Academy of Management Review, 18(2), 293-321. https://doi.org/10.5465/amr.1993.3997517

Woodward, J. (1965). Industrial organization: Theory and practice. New York: Oxford University Press.

Worline, M., \& Quinn, R. (2003). Courageous principled action. In K. S. Cameron, J. E. Dutton, \& R. E. Quinn (Eds.), Positive organizational scholarship(pp.138-157). San Francisco, CA: Berrett-Koehler.

Yang, K. P., \& Mao, X. Y. (2007). A study of nurses' spiritual intelligence: A cross - sectional questionnaire survey. Journal of Nursing Studies, 44(6), 999-1010. https://doi.org/10.1016/j.ijnurstu.2006.03.00

Yu, T., Gudergan, S., \& Chen, C. F. (2018). Achieving employee efficiency-flexibility ambidexterity. The International Journal of Human Resource Management, 31(19), 2459-2494. https://doi.org/10.1080/09585192.2018.1449762

Zhou, J., \& George, J.M. (2003). Awakening employee creativity: The role of leader emotional intelligence. The Leadership Quarterly, 14(4), 545-568. https://doi.org/10.1016/S10489843(03)00051-1 